\title{
DAMPAK ALIH FUNGSI LAHAN SAWAH TERHADAP KETAHANAN PANGAN DI DAERAH ISTIMEWA YOGYAKARTA
}

\author{
The Impact Of Wetland Conversion On Food Security In Daerah Istimewa \\ Yogyakarta
}

I Made Yoga Prasada1, Tia Alfina Rosa ${ }^{2}$

1,2Program Pascasarjana, Fakultas Pertanian Universitas Gadjah Mada ${ }^{*}$ Kontak penulis: imade.yogap@gmail.com

\begin{abstract}
An increased in economic growth requires a transformation in economic activities in Daerah Istimewa Yogyakarta, thus encouraging an increased in conversion of wetlands into non-agricultural lands. The conversion of wetlands can cause a negative impact on food availability and food security. Therefore, the reseacrh was conducted to determine the impact of the conversion of wetlands to the people food security in Daerah Istimewa Yogyakarta. The data used in this research is secondary data obtained from Badan Pusat Statistik Daerah Istimewa Yogyakarta in 2006 to 2015. The people food security is calculated using the food surplus/deficit method. In addition, this research using paired sample t test to determine the differences between food security before and after the conversion of wetlands occurred. The results showed that the conversion of wetlands led to the loss of rice production by 18.359,27 tons during the period 2006-2015. However, the people food security is maintained even though there are conversion of wetlands. The t test shows that there are significant differences in food security between before and after the conversion of wetlands occured.
\end{abstract}

Keywords: conversion, Daerah Istimewa Yogyakarta, food security, wetlands.

Abstrak

Meningkatnya pertumbuhan ekonomi menuntut terjadinya transformasi dalam kegiatankegiatan perekonomian di Daerah Istimewa Yogyakarta, sehingga mendorong meningkatnya alih fungsi lahan sawah menjadi lahan-lahan non pertanian. Alih fungsi lahan sawah dapat memberikan dampak negative terhadap ketersediaan pangan dan ketahanan pangan penduduk. Oleh karena itu, penelitian dilakukan untuk mengetahui dampak alih fungsi lahan sawah terhadap ketahanan pangan penduduk di Daerah Istimewa Yogyakarta. Data yang digunakan pada penelitian ini adalah data sekunder yang diperoleh dari Badan Pusat Statistik Daerah Istimewa Yogyakarta tahun 2006 hingga tahun 2015. Ketahanan pangan penduduk dihitung dengan menggunakan metode surplus/deficit pangan. Selain itu, pada penelitian ini menggunakan analisis stastistik uji paired sample $\mathrm{t}$ test untuk mengetahui perbedaan ketahanan pangan sebelum dan sesudah alih fungsi lahan sawah terjadi. Hasil penelitian menunjukkan bahwa alih fungsi lahan sawah menyebabkan hilangnya produksi beras sebesar 18.359,27 ton selama periode tahun 2006-2015. Akan tetapi, ketahanan pangan penduduk tetap terjaga meskipun terjadi alih fungsi lahan sawah. Uji t menunjukkan terdapat beda signifikan tingkat ketahanan pangan penduduk antara sebelum dan sesudah terjadinya alih fungsi lahan sawah.

Kata kunci: Alih fungsi lahan, Daerah Istimewa Yogyakarta, ketahanan pangan, lahan sawah.

Sitasi: Prasada I. M. Y. T. A. Rosa, 2018. Dampak Alih Fungsi Lahan Sawah Terhadap Ketahanan Pangan Di Daerah Istimewa Yogyakarta Antique, JSEP 14(3): 210 - 224. 


\section{Pendahuluan}

Transformasi ekonomi merupakan tantangan besar yang dihadapi oleh sektor pertanian. Terjadinya transformasi ekonomi dapat memberikan konsekuensi terhadap meningkatnya kebutuhan lahan untuk sektor non pertanian. Di sisi lain, luas lahan di suatu wilayah cenderung bersifat tetap, sehingga peningkatan permintaan lahan untuk suatu sektor ekonomi tertentu hanya dapat dipenuhi dengan melakukan alih fungsi pada penggunaan lahan di sektor lainnya baik sektor produksi pangan, energi, dan kehutanan (Harahap et al., 2017; Mahmood et al., 2016). Lahan pertanian adalah lahan yang paling banyak digunakan untuk kegiatan alih fungsi lahan. Hal ini disebabkan karena luas lahan di sektor pertanian relatif lebih besar dibandingkan dengan luas lahan di sektor lainnya, sehingga lahan pertanian dianggap sangat potensial untuk dilakukan alih fungsi lahan untuk sektor non pertanian (Millar \& Roots, 2012). Alih fungsi lahan pertanian telah terjadi diberbagai provinsi di Indonesia, termasuk Daerah Istimewa Yogyakarta. Daerah Istimewa Yogyakarta sebagai kota pelajar dan kota wisata telah terjadi peningkatan permintaan lahan untuk berbagai kepentingan non pertanian seperti rumah tinggal, investasi, bisnis pergudangan, sentra industri, dan pariwisata (Prihatin, 2015), sehingga mendorong terjadinya alih fungsi lahan pertanian menjadi lahan non pertanian. Daerah Istimewa Yogyakarta mengalami konsistensi alih fungsi lahan sawah sejak tahun 1990 hingga 2015. Berdasarkan data dari Badan Pusat Statistik Daerah Istimewa Yogyakarta (2016), luas sawah di Daerah Istimewa Yogyakarta pada sepuluh tahun terakhir (2006-2015) mengalami penurunan sebasar 4,82\% dengan laju penurunan rata-rata sebesar $0,48 \%$ per tahun.

Lahan pertanian adalah jenis lahan yang paling banyak dialihfungsikan terutama lahan sawah. Hal ini terjadi akibat rendahnya insentif atau pendapatan yang diterima oleh petani selama mengelola lahan sawah dibandingkan dengan penggunaan untuk kegiatan untuk sektor lainnya (Daulay et al., 2016; Demmallino et al., 2018). Tingginya laju alih fungsi lahan sawah memberikan implikasi terhadap menurunnya ketersediaan pangan bagi penduduk sehingga akan berdampak pada penurunan produksi pangan khususnya beras yang dapat memberikan ancaman bagi ketahanan pangan penduduk. Ketahanan pangan dapat tercapai jika pangan yang tersedia dapat memenuhi kebutuhan pangan seluruh penduduk Indonesia (UU No. 18 Tahun 2012). Kebutuhan pangan penduduk diperkirakan akan semakin meningkat seiring dengan peningkatan jumlah penduduk (Sunanto \& Rauf, 2018). Jumlah penduduk yang meningkat menuntut ketersediaan pangan dan produksi pangan yang semakin tinggi ditengah terjadinya alih fungsi lahan pertanian tanaman pangan yang semakin besar di Daerah Istimewa Yogyakarta.

Studi terkait alih fungsi lahan pertanian telah dilakukan untuk mengetahui berbagai dampak yang mungkin terjadi dari adanya alih fungsi lahan pertanian tersebut. Saputra \& Budhi (2015) melakukan penelitian terkait dengan dampak alih fungsi lahan pertanian terhadap kondisi ekonomi petani jambu mete dan menyatakan bahwa faktor ekonomi merupakan faktor penentu utama bagi petani untuk mengalihfungsikan lahan pertanian yang dimilikinya. Rohmadiani (2011) dalam penelitiannya tentang alih fungsi lahan pertanian menyimpulkan bahwa alih fungsi lahan pertanian yang terjadi di Kecamatan Pamanukan berdampak pada perubahan struktur mata pencaharian petani. Nurpita dkk (2018) menggunakan data 
primer untuk mengetahui ketahanan pangan rumah tangga tani di Kecamatan Temon dan menunjukkan bahwa terdapat perbedaan yang signifikan antara ketahanan pangan rumah tangga tani sebelum dan sesudah alih fungsi lahan dilakukan. Penelitian-penelitian yang telah dilakukan terkait alih fungsi lahan pertanian menggunakan data primer dan menggunakan pendekatan mikro dalam analisis yang dilakukan dan belum menyatakan potensi kehilangan produksi yang terjadi akibat alih fungsi lahan dan dampaknya terhadap ketahanan pangan di suatu wilayah. Oleh karena itu, penelitian ini dilakukan dengan tujuan untuk mengetahui luas dan laju alih fungsi lahan sawah di Daerah Istimewa Yogyakarta selama periode 2006-2015, jumlah kehilangan hasil produksi padi akibat alih fungsi lahan sawah dan dampaknya terhadap ketahanan pangan di Daerah Istimewa Yogyakarta.

\section{Metode Penelitian}

Penelitian ini menggunakan data sekunder yang diperoleh dari Badan Pusat Statistik Daerah Istimewa Yogyakarta tahun 2006 hingga tahun 2015. Metode perhitungan dan analisis yang digunakan sebagai berikut:;

1. Produksi padi yang hilang

Metode ini digunakan untuk menjawab jumlah kehilangan hasil produksi padi akibat alih fungsi lahan sawah dengan menggunakan data produktivitas (ton/ha) dan luas alih fungsi lahan sawah (ha).

$$
\mathrm{PPH}=\mathrm{Pdvt} \times \mathrm{At}
$$

Keterangan:

$\mathrm{PPH}=$ Produksi padi yang hilang (ton)

Pdvt = Produktivitas padi (ton/ha)

At = Luas alih fungsi lahan sawah (ha)

2. Ketahanan pangan (surplus/defisit)

Metode ini digunakan untuk mengetahui dampak alih fungsi lahan sawah terhadap ketahanan pangan. Ketahanan pangan penduduk pada dasarnya dapat tercapai saat jumlah pangan yang tersedia di suatu wilayah dapat mencukupi seluruh kebutuhan pangan masyarakatnya.

A. Pangan Tersedia

Pangan tersedia, dihitung dengan cara :

Pangan tersedia $=$ produksi padi bruto - faktor konversi padi

Faktor-faktor konversi padi yaitu padi untuk kebutuhan bibit, padi untuk kebutuhan pakan, padi untuk kebutuhan industri non pangan, dan padi tercecer (Badan Ketahanan Pangan dan Penyuluhan dalam publikasi Neraca Bahan Makanan Indonesia).

B. Konsumsi Pangan dan Kebutuhan Pangan

Konsumsi pangan penduduk di Daerah Istimewa Yogyakarta dapat tercermin dari data pengeluaran per kapita penduduk per bulan untuk padi-padian. Data tersebut kemudian dibagi dengan harga beras yang berlaku pada tahun bersangkutan untuk mendapatkan data konsumsi beras penduduk per kapita per bulan. Setelah itu, data konsumsi per kapita dapat dikalikan dengan jumlah penduduk pada masing-masing tahun untuk mengetahui kebutuhan pangan penduduk. 


\section{Ketahanan Pangan}

Ketahanan pangan dapat tercermin dari surplus atau defisit pangan yang terjadi di suatu wilayah. Surplus/defisit pangan dapat dihitung dengan menggunakan selisih pangan tersedia dengan pangan yang dibutuhkan (Darsono, 2012). Kategori surplus/defisit adalah sebagai berikut:

Surplus $\quad=$ pangan tersedia $>$ atau $=$ kebutuhan pangan (tahan pangan)

Defisit $\quad=$ pangan tersedia $<$ kebutuhan pangan (tidak tahan pangan)

Pangan dengan nilai surplus yang semakin besar di suatu wilayah menunjukkan semakin tingginya tingkat ketahanan pangan masyarakat di wilayah tersebut, semakin tinggi defisit pangan yang terjadi menyebabkan semakin rendahnya tingkat ketahanan pangan masyarakat.

\section{Paired sample t-test}

Paired sample t-test adalah teknik statistik yang digunakan untuk membandingkan dua berkorelasi. Paired sample t-test digunakan dalam observasi "before-after" dalam subjek yang sama (Lani, 2010). Metode ini digunakan untuk mengetahui ada/tidaknya perbedaan tingkat ketahanan pangan sebelum dan sesudah alih fungsi lahan sawah. Paired sample $t$ test dapat memberikan gambaran apakah alih fungsi lahan sawah dapat/tidak berpengaruh signifikan terhadap tingkat ketahanan pangan penduduk.

\section{Hasil Dan Pembahasan}

\section{Luas Dan Laju Alih Fungsi Lahan Sawah}

Alih fungsi lahan merupakan kegiatan yang dilakukan untuk mengubah fungsi suatu jenis lahan menjadi fungsi lainnya. Berbagai jenis lahan dapat dialihfungsikan menjadi berbagai jenis fungsi lain yang dapat memberikan manfaat dan biaya yang berbeda-beda dari kegiatan pemanfaatan lahan tersebut. Jenis lahan yang cukup banyak dialihfungsikan adalah lahan pertanian, khususnya lahan pertanian tanaman pangan yaitu lahan sawah. Lahan sawah mengalami konversi yang sangat besar selama sepuluh tahun terakhir. Berdasarkan data Badan Pusat Statistik Daerah Istimewa Yogyakarta (2016) selama sepuluh tahun terakhir (20062015) telah terjadi alih fungsi lahan sawah yang konsisten. Perkembangan luas alih fungsi lahan dan laju alih fungsi lahan sawah dapat dilihat pada Tabel 1.

Berdasarkan Tabel 1 dapat diketahui bahwa luas lahan sawah cukup berfluktuasi pada setiap tahunnya. Perubahan luas lahan sawah ini disebabkan karena telah terjadinya percetakan atau pembukaan lahan sawah baru dan terjadinya kegiatan alih fungsi lahan sawah. Pada periode tahun 2006 hingga tahun 2015 telah terjadi alih fungsi lahan sawah sebesar 3.089 hektar dengan rata-rata luas lahan sawah yang dikonversikan adalah 308,90 hektar per tahun. Angka tersebut merupakan angka yang sangat besar jika dibandingkan dengan angka pembukaan lahan sawah yang terjadi pada periode yang sama, yang hanya mencapai angka 424 hektar selama 10 tahun atau 42,40 hektar per tahunnya. Angka laju penyusutan lahan juga cukup besar yaitu rata-rata $0,48 \%$ per tahun. Alih fungsi lahan sawah yang lebih besar dibandingkan dengan pembukaan lahan sawah mengindikasikan adanya potensi kehilangan hasil produksi pangan yang besar, sehingga hal ini dapat memberikan ancaman bagi ketahanan pangan penduduk. Tingginya laju alih fungsi lahan sawah ini dapat disebabkan karena meningkatnya jumlah penduduk yang 
mendorong semakin meningkatnya kebutuhan permukiman (Gardi et al., 2015; Jiang \& Zhang, 2016). Selain itu, meningkatnya kebutuhan lahan untuk kegiatan non pertanian meliputi kegiatan industri, perdagangan dan lain sebagainnya turut berpengaruh terhadap tingginya laju alih fungsi lahan sawah (Yasar \& Siwar, 2016). Tingginya laju alih fungsi lahan sawah juga dapat disebabkan karena tidak adanya insentif bagi petani untuk mempertahankan sawah yang dikelolanya, sehingga tidak ada keinginan dari petani untuk tetap mempertahankan lahan sawah tersebut.

Tabel 1

Luas Dan Laju Alih Fungsi Lahan Sawah Di Daerah Istimewa Yogyakarta (2006-2015)

\begin{tabular}{lrrrr}
\hline Tahun & $\begin{array}{r}\text { Luas } \\
\text { Lahan } \\
\text { Sawah } \\
(\text { ha) }\end{array}$ & $\begin{array}{r}\text { Luas Alih Fungsi } \\
\text { Lahan Sawah (ha) }\end{array}$ & $\begin{array}{r}\text { Luas Pembukaan } \\
\text { Lahan Sawah (ha) }\end{array}$ & $\begin{array}{r}\text { Laju Penyusutan } \\
\text { Luas Lahan Sawah } \\
(\%)\end{array}$ \\
\hline 2006 & $56.218,00$ & 0,00 & 0,00 & 0,00 \\
2007 & $55.540,00$ & 678,00 & 0,00 & $-1,21$ \\
2008 & $55.332,00$ & 208,00 & 0,00 & $-0,37$ \\
2009 & $55.325,00$ & 7,00 & 0,00 & $-0,01$ \\
2010 & $55.523,00$ & 0,00 & 198,00 & 0,36 \\
2011 & $55.291,00$ & 232,00 & 0,00 & $-0,42$ \\
2012 & $55.110,00$ & 181,00 & 0,00 & $-0,33$ \\
2013 & $55.336,00$ & 0,00 & 226,00 & 0,41 \\
2014 & $54.417,00$ & 919,00 & 0,00 & $-1,66$ \\
2015 & $53.553,00$ & 864,00 & 0,00 & $-1,59$ \\
\hline Total & $551.645,00$ & $3.089,00$ & 424,00 & $-4,82$ \\
Rata-rata & $55.164,50$ & 308,90 & 42,40 & $-0,48$ \\
\hline Sumber: BPS & $(2016)$ & & &
\end{tabular}

\section{Dampak Alih Fungsi Lahan Sawah Terhadap Produksi Padi}

Alih fungsi lahan sawah memiliki dampak terhadap terjadinya kehilangan produksi pangan. Alih fungsi lahan yang semakin besar mendorong semakin besarnya potensi kehilangan produksi pangan bagi masyarakat. Pada periode tahun 2006 hingga tahun 2015 dapat diketahui bahwa di Daerah Istimewa Yogyakarta telah terjadi alih fungsi lahan pertanian sebesar 3.089 hektar. Kehilangan lahan sebesar 3.089 hektar berarti bahwa telah kehilangan produksi padi sebesar 18.359,27 ton. Data perkembangan produksi padi yang hilang akibat alih fungsi lahan sawah dapat dilihat pada Tabel 2.

Berdasarkan Tabel 2 dapat diketahui bahwa nilai produksi padi yang hilang akibat terjadinya alih fungsi lahan sawah sangat bervariasi pada setiap tahunnya. Variasi ini mengikuti angka besaran alih fungsi lahan yang terjadi pada setiap tahun dan produktivitas panen padi pada tahun yang bersangkutan. Hal ini memberikan gambaran bahwa semakin besar alih fungsi lahan sawah yang terjadi, maka akan semakin besar nilai produksi padi yang hilang akibat kegiatan alih fungsi lahan sawah tersebut. Selain itu, nilai produksi yang hilang akan semakin besar saat nilai produktivitas panen padi semakin meningkat. Hasil penelitian ini sejalan dengan penelitian yang dilakukan oleh Hidayat dkk. (2017) yang menunjukkan bahwa 
terjadinya alih fungsi lahan pertanian di Kecamatan Kertajati, Kabupaten Majalengka dapat menyebabkan hilangnya potensi produksi gabah kering giling sebesar 15.271 ton per tahun.

Tabel 2

Dampak Alih Fungsi Lahan Sawah Terhadap Hilangnya Produksi Padi (2006-2015)

\begin{tabular}{lrrr}
\hline Tahun & $\begin{array}{r}\text { Produktivitas } \\
\text { (ton/ha) }\end{array}$ & $\begin{array}{r}\text { Luas Alih Fungsi Lahan } \\
\text { Sawah (ha) }\end{array}$ & $\begin{array}{r}\text { Produksi Padi yang } \\
\text { Hilang (ton) }\end{array}$ \\
\hline 2006 & 5,35 & 0,00 & 0,00 \\
2007 & 5,82 & 678,00 & $3.948,03$ \\
2008 & 5,69 & 208,00 & $1.184,53$ \\
2009 & 6,27 & 7,00 & 43,90 \\
2010 & 6,05 & 0,00 & 0,00 \\
2011 & 6,05 & 232,00 & $1.403,80$ \\
2012 & 6,74 & 181,00 & $1.220,70$ \\
2013 & 5,79 & 0,00 & 0,00 \\
2014 & 5,79 & 919,00 & $5.318,26$ \\
2015 & 6,06 & 864,00 & $5.240,04$ \\
\hline Total & 59,62 & $3.089,00$ & $18.359,27$ \\
Rata- & 5,96 & 308,90 & $1.835,93$ \\
rata & & & \\
\hline
\end{tabular}

Sumber: BPS (2016)

\section{Perkembangan Ketersediaan Beras}

Beras tersedia merupakan beras yang benar-benar tersedia dan dapat dikonsumsi oleh masyarakat. Beras tersedia dapat dihitung dengan menggunakan faktor konversi ketersediaan beras yang diperoleh melalui data padi tersedia (BKPP, 2016). Padi tersedia dapat dihitung dengan memperhitungkan faktor konversi ketersediaan padi. Ketersediaan beras menjadi informasi yang sangat penting untuk mengetahui seberapa besar beras yang tersedia yang diproduksi oleh suatu wilayah pada suatu waktu tertentu (Santosa, 2017). Sebelum menghitung ketersediaan beras, maka perlu dilakukan perhitungan terhadap ketersediaan padi seperti terlihat pada Tabel 3.

Padi tersedia dapat dihitung dengan mengurangkan data produksi padi bruto dengan faktor-faktor konversi yang dipertimbangkan (Swaminathan \& Bhavani, 2013). Faktor konversi ketersediaan padi antara lain padi untuk kebutuhan bibit, padi untuk kebutuhan pakan, industri non pangan, dan padi tercecer. Data faktor konversi tersebut dapat diperoleh melalui data dari BKPP (Badan Ketahanan Pangan dan Penyuluhan) dalam publikasi Neraca Bahan Makanan (NBM) Indonesia. 
Tabel 3

Padi Tersedia Di Daerah Istimewa Yogyakarta (2006-2015)

\begin{tabular}{|c|c|c|c|c|c|c|}
\hline \multirow[b]{2}{*}{ Tahun } & \multirow[b]{2}{*}{$\begin{array}{r}\text { Prod GKG } \\
\text { (ton) }\end{array}$} & \multicolumn{4}{|c|}{ Faktor Koreksi Ketersediaan Padi } & \multirow[b]{2}{*}{$\begin{array}{r}\text { Ketersediaan } \\
\text { GKG (ton) }\end{array}$} \\
\hline & & $\begin{array}{r}\text { Kebutuhan } \\
\text { Bibit (\%) }\end{array}$ & $\begin{array}{r}\text { Padi } \\
\text { Pakan } \\
(\%)\end{array}$ & $\begin{array}{r}\text { Padi } \\
\text { Tercecer } \\
(\%)\end{array}$ & $\begin{array}{r}\text { Padi } \\
\text { Industri } \\
\text { Non } \\
\text { Pangan }(\%)\end{array}$ & \\
\hline 2006 & $708.163,00$ & 0,90 & 0,44 & 5,40 & 0,56 & $656.467,10$ \\
\hline 2007 & $570.991,00$ & 0,90 & 0,44 & 5,40 & 0,56 & $529.308,66$ \\
\hline 2008 & $798.232,00$ & 0,90 & 0,44 & 5,40 & 0,56 & $739.961,06$ \\
\hline 2009 & $662.368,00$ & 0,90 & 0,44 & 5,40 & 0,56 & $614.015,14$ \\
\hline 2010 & $646.816,00$ & 0,90 & 0,44 & 5,40 & 0,56 & $599.598,43$ \\
\hline 2011 & $653.434,00$ & 0,90 & 0,44 & 5,40 & 0,56 & $605.733,32$ \\
\hline 2012 & $737.446,00$ & 0,90 & 0,44 & 5,40 & 0,56 & $683.612,44$ \\
\hline 2013 & $921.824,00$ & 0,90 & 0,44 & 5,40 & 0,56 & $854.530,85$ \\
\hline 2014 & $919.573,00$ & 0,90 & 0,44 & 5,40 & 0,56 & $852.444,17$ \\
\hline 2015 & $945.136,00$ & 0,90 & 0,44 & 5,40 & 0,56 & $876.141,07$ \\
\hline Total & $7.563 .983,00$ & 9,00 & 4,40 & 54,00 & 5,60 & $7.011 .812,24$ \\
\hline Rata-rata & $756.398,30$ & 0,90 & 0,44 & 5,40 & 0,56 & $701.181,22$ \\
\hline
\end{tabular}

Sumber: BPS (2016)

Berdasarkan Tabel 4 dapat diketahui bahwa ketersediaan padi di Daerah Istimewa Yogyakarta setiap tahun rata-rata sebesar 701.181,22 ton. Nilai padi tersebut merupakan nilai padi yang benar-benar tersedia rata-rata per tahun. Nilai produksi padi tersebut kemudian dapat dikonversikan ke bentuk produksi beras dengan mengalikan hasil produksi padi tersedia dengan faktor konversi Gabah Kering Giling (GKG) ke beras. Produksi beras tahun 2006 hingga tahun 2015 dapat dilihat pada Tabel 4 .

Tabel 4

Produksi Beras Di Daerah Istimewa Yogyakarta (2006-2015)

\begin{tabular}{lrrr}
\hline Tahun & $\begin{array}{r}\text { Ketersediaan GKG } \\
(\text { ton })\end{array}$ & $\begin{array}{r}\text { Faktor Konversi GKG ke } \\
\text { beras }(\%)\end{array}$ & $\begin{array}{r}\text { Produksi Beras } \\
\text { (ton) }\end{array}$ \\
\hline 2006 & $656.467,10$ & 63,20 & $414.887,21$ \\
2007 & $529.308,66$ & 63,20 & $334.523,07$ \\
2008 & $739.961,06$ & 63,20 & $467.655,39$ \\
2009 & $614.015,14$ & 62,70 & $384.987,49$ \\
2010 & $599.598,43$ & 62,70 & $375.948,22$ \\
2011 & $605.733,32$ & 62,70 & $379.794,79$ \\
2012 & $683.612,44$ & 62,70 & $428.625,00$ \\
2013 & $854.530,85$ & 62,70 & $535.790,84$ \\
2014 & $852.444,17$ & 62,70 & $534.482,50$ \\
2015 & $876.141,07$ & 62,70 & $549.340,45$ \\
\hline Total & $7.011 .812,24$ & 628,50 & $4.406 .034,96$ \\
Rata-Rata & $701.181,22$ & 62,85 & $440.603,50$ \\
\hline
\end{tabular}

Sumber: BPS (2016) 
Faktor konversi GKG ke beras diperoleh melalui publikasi Neraca Bahan Makanan (NBM) Indonesia. Tabel 4 menunjukkan bahwa rata-rata nilai faktor konversi GKG ke beras hasil publikasi NBM adalah sebesar 62,85\%. Nilai tersebut menghasilkan produksi beras total sejak tahun 2006 hingga tahun 2015 sebesar 4.406.034,96 ton atau dengan kata lain sejak tahun 2006 hingga tahun 2015 dapat memproduksi beras rata-rata sebesar $440.603,50$ ton per tahun. Hasil produksi beras tersebut merupakan produksi beras bruto yang mampu dihasilkan. Beras tersebut bukan merupakan beras yang tersedia yang dapat dikonsumsi oleh masyarakat untuk memenuhi kebutuhan pangan sehari-hari. Oleh karena itu, perlu dilakukan perhitungan untuk mengetahui jumlah beras tersedia yang dapat dihasilkan pada tahun 2006 hingga tahun 2015. Nilai beras tersedia dapat dihitung dengan memperhitungkan adanya faktor konversi beras tersedia. Faktor konversi tersebut dapat diperoleh melalui publikasi Neraca Bahan Makanan (NBM) Indonesia yang dipublikasikan oleh BKPP Indonesia. Jumlah beras tersedia yang mampu diproduksi pada tahun 2006 hingga tahun 2015 dapat dilihat pada Tabel 5.

Tabel 5

Produksi Beras Tersedia Di Daerah Istimewa Yogyakarta (2006-2015)

\begin{tabular}{lrrrrr}
\hline & & \multicolumn{2}{c}{ Faktor Koreksi Ketersediaan Beras } & \\
\cline { 3 - 4 } Tahun & $\begin{array}{r}\text { Produksi } \\
\text { Beras (ton) }\end{array}$ & $\begin{array}{r}\text { Beras } \\
\text { Pakan } \\
(\%)\end{array}$ & $\begin{array}{r}\text { Beras } \\
\text { Tercecer } \\
(\%)\end{array}$ & $\begin{array}{r}\text { Beras ke } \\
\text { industri NP }\end{array}$ & $\begin{array}{r}\text { Ketersediaan Beras } \\
(\%)\end{array}$ \\
\hline 2006 & $414.887,21$ & 0,17 & 2,50 & 0,66 & $401.071,46$ \\
2007 & $334.523,07$ & 0,17 & 2,50 & 0,66 & $323.383,45$ \\
2008 & $467.655,39$ & 0,17 & 2,50 & 0,66 & $452.082,47$ \\
2009 & $384.987,49$ & 0,17 & 2,50 & 0,66 & $372.167,41$ \\
2010 & $375.948,22$ & 0,17 & 2,50 & 0,66 & $363.429,14$ \\
2011 & $379.794,79$ & 0,17 & 2,50 & 0,66 & $367.147,62$ \\
2012 & $428.625,00$ & 0,17 & 2,50 & 0,66 & $414.351,79$ \\
2013 & $535.790,84$ & 0,17 & 2,50 & 0,66 & $517.949,01$ \\
2014 & $534.482,50$ & 0,17 & 2,50 & 0,66 & $516.684,23$ \\
2015 & $549.340,45$ & 0,17 & 2,50 & 0,66 & $531.047,42$ \\
\hline Total & $4.406 .034,96$ & 1,70 & 25,00 & 6,60 & $4.259 .314,00$ \\
Rata-Rata & $440.603,50$ & 0,17 & 2,50 & 0,66 & $425.931,40$ \\
\hline
\end{tabular}

Sumber: BPS (2016)

Berdasarkan Tabel 5 dapat diketahui bahwa sejak tahun 2006 hingga tahun 2015 daerah ini mampu memproduksi beras netto (beras tersedia) sebesar 4.259.314,00 ton atau rata-rata sebesar 425.931,40 ton per tahun. Nilai tersebut merupakan nilai produksi beras netto, yaitu nilai produksi beras bruto yang telah dikurangkan dengan faktor konversi ketersediaan beras. Faktor konversi ketersediaan beras antara lain beras untuk pakan, beras untuk kebutuhan industri non pangan dan beras yang tercecer. Angka beras tersedia pada Tabel 5 menunjukkan jumlah ketersediaan beras yang dapat dikonsumsi oleh penduduk di wilayah tersebut. Angka ketersediaan beras cenderung meningkat sejak tahun 2006 hingga tahun 2015 walaupun telah terjadi alih fungsi lahan sawah yang besar. Hal ini dapat disebabkan karena adanya peningkatan produktivitas padi sawah (Tabel 2). 
Peningkatan produktivitas pada dasaranya akan sangat berpengaruh terhadap meningkatnya jumlah produksi pangan di suatu wilayah (Wahed, 2015). Jumlah ketersediaan beras yang semakin besar dapat menunjang terpenuhinya kebutuhan pangan bagi masyarakat, dan sebaliknya ketersediaan beras yang semakin kecil dapat mengancam terpenuhinya kebutuhan pangan masyarakat di suatu wilayah. Kebutuhan pangan masyarakat yang dapat terpenuhi dengan baik dapat menunjang tercapainya ketahanan pangan masyarakat tersebut.

\section{Perkembangan Konsumsi dan Kebutuhan Beras}

Pemenuhan kebutuhan pangan masyarakat menjadi syarat yang penting untuk tercapainya ketahanan pangan masyarakat. Konsumsi merupakan suatu kegiatan untuk menghabiskan nilai manfaat dari suatu barang atau jasa. Penduduk Indonesia mayoritas memanfaatkan beras sebagai konsumsi pangan pokok tak terkecuali dengan penduduk. Konsumsi beras penduduk dapat tercermin dari besarnya pengeluaran pangan (beras) per kapita masyarakat per bulan. Pengeluaran per kapita untuk konsumsi pangan berupa beras kemudian dapat dikonversikan dengan harga nominal beras yang berlaku pada setiap tahunnya menjadi konsumsi beras per kapita penduduk. Konsumsi beras penduduk dapat dilihat pada Tabel 6 .

Tabel 6

Konsumsi Beras Per Kapita Penduduk Di Daerah Istimewa Yogyakarta (2006-2015)

\begin{tabular}{lrrrr}
\hline \multirow{2}{*}{ Tahun } & $\begin{array}{r}\text { Harga Nominal } \\
\text { Beras }(\mathrm{Rp} / \mathrm{kg})\end{array}$ & $\begin{array}{r}\text { Pengeluaran Per } \\
\text { Kapita Per Bulan } \\
(\mathrm{Rp})\end{array}$ & $\begin{array}{r}\text { Pengeluaran Per } \\
\text { Kapita Per tahun } \\
(\mathrm{Rp})\end{array}$ & $\begin{array}{r}\text { Konsumsi } \\
\text { Beras } \\
(\mathrm{kg} / \mathrm{kap} / \mathrm{thn})\end{array}$ \\
\hline 2006 & $3.976,04$ & $25.483,00$ & $305.796,00$ & 76,91 \\
2007 & $4.760,42$ & $27.342,00$ & $328.104,00$ & 68,92 \\
2008 & $4.798,00$ & $23.381,00$ & $280.572,00$ & 58,48 \\
2009 & $5.090,00$ & $23.900,00$ & $286.800,00$ & 56,35 \\
2010 & $6.052,00$ & $32.058,00$ & $384.696,00$ & 63,57 \\
2011 & $6.931,00$ & $32.702,00$ & $392.424,00$ & 56,62 \\
2012 & $7.627,00$ & $41.670,00$ & $500.040,00$ & 65,56 \\
2013 & $7.888,50$ & $45.421,00$ & $545.052,00$ & 69,09 \\
2014 & $8.150,00$ & $45.226,00$ & $542.712,00$ & 66,59 \\
2015 & $9.120,00$ & $46.511,00$ & $558.132,00$ & 61,20 \\
\hline Total & $64.392,96$ & $343.694,00$ & $4.124 .328,00$ & 643,28 \\
Rata-rata & $6.439,30$ & $34.369,40$ & $412.432,80$ & 64,33 \\
\hline
\end{tabular}

Sumber: BPS (2016)

Berdasarkan Tabel 6 dapat diketahui bahwa konsumsi beras per kapita penduduk mengalami fluktuasi pada setiap tahunnya. Pada periode tahun 2006 hingga tahun 2015 dapat terlihat konsumsi beras tertinggi terjadi pada tahun 2006 dan cenderung menurun pada tahun-tahun berikutnya. Konsumsi beras per kapita penduduk rata-rata sebesar $64,33 \mathrm{~kg} / \mathrm{kapita} /$ tahun. Konsumsi beras per kapita penduduk yang relatif menurun dapat disebabkan karena adanya diversifikasi pangan, sehingga mengurangi ketergantungan terhadap konsumsi beras (Lastinawati, 2010; Sukesi \& Shinta, 2011). Cenderung menurunnya konsumsi beras per kapita penduduk memiliki konsekuensi positif terhadap menurunnya jumlah 
beras yang dibutuhkan untuk memenuhi kebutuhan pokok penduduk. Hal ini dapat mempercepat terwujudnya ketahanan pangan penduduk di wilayah tersebut.

Konsumsi per kapita penduduk jika dikalikan dengan jumlah penduduk, maka akan diketahui jumlah kebutuhan beras. Kebutuhan beras tersebut merupakan jumlah beras yang harus dipenuhi untuk menunjang ketahanan pangan penduduk. Kebutuhan beras penduduk dapat dilihat pada Tabel 7.

Tabel 7

Kebutuhan Beras Penduduk Di Daerah Istimewa Yogyakarta (2006-2015)

\begin{tabular}{lrrrr}
\hline Tahun & $\begin{array}{r}\text { Konsumsi Beras } \\
(\mathrm{kg} / \mathrm{kap} / \mathrm{thn})\end{array}$ & $\begin{array}{r}\text { Jumlah } \\
\text { Penduduk (Jiwa) }\end{array}$ & $\begin{array}{r}\text { Total Kebutuhan } \\
\text { Beras }(\mathrm{kg} / \mathrm{thn})\end{array}$ & $\begin{array}{r}\text { Total } \\
\text { Kebutuhan } \\
\text { Beras } \\
\text { (ton/thn) }\end{array}$ \\
\hline 2006 & & $3.389 .000,00$ & $260.646 .936,15$ & $260.646,94$ \\
2007 & 76,91 & $3.434 .500,00$ & $236.717 .177,90$ & $236.717,18$ \\
2008 & 68,92 & $3.468 .500,00$ & $202.827 .007,50$ & $202.827,01$ \\
2009 & 58,48 & $3.501 .900,00$ & $197.317 .273,08$ & $197.317,27$ \\
2010 & 56,35 & $3.457 .491,00$ & $219.775 .769,62$ & $219.775,77$ \\
2011 & 63,57 & $3.509 .997,00$ & $198.731 .360,95$ & $198.731,36$ \\
2012 & 56,62 & $3.552 .462,00$ & $232.905 .873,67$ & $232.905,87$ \\
2013 & 65,56 & $3.594 .854,00$ & $248.384 .656,45$ & $248.384,66$ \\
2014 & 69,09 & $3.637 .116,00$ & $242.197 .116,39$ & $242.197,12$ \\
2015 & 66,59 & $3.679 .176,00$ & $225.160 .730,18$ & $225.160,73$ \\
\hline Total & 61,20 & $35.224 .996,00$ & $2.264 .663 .901,89$ & $2.264 .663,90$ \\
Rata-rata & 643,28 & $3.522 .499,60$ & $226.466 .390,19$ & $226.466,39$ \\
\hline Sumber: BPS (2016) & 64,33 & & &
\end{tabular}

Berdasarkan Tabel 7 dapat diketahui bahwa rata-rata kebutuhan beras penduduk pada periode tahun 2006 hingga tahun 2015 sebesar 226.466,39 ton per tahun. Kebutuhan beras penduduk cenderung menurun pada setiap tahunnya. Hal ini dapat terjadi karena semakin menurunnya konsumsi beras per kapita penduduk walaupun telah terjadi kecenderungan naiknya jumlah penduduk. Kebutuhan beras penduduk akan semakin menurun saat konsumsi per kapita penduduk semakin menurun dan jumlah penduduk semakin menurun atau laju peningkatan jumlah penduduk tidak lebih besar dari laju penurunan konsumsi per kapita penduduk dan sebaliknya. Kedua indikator tersebut perlu diperhatikan untuk menjaga tingkat ketahanan pangan penduduk.

\section{Dampak Alih Fungsi Lahan Terhadap Ketahanan Pangan Penduduk}

Terjadinya alih fungsi lahan sawah menjadi lahan-lahan non sawah memberikan dampak terhadap semakin menurunnya jumlah lahan yang dapat dimanfaatkan untuk kegiatan budidaya tanaman pangan. Hal ini berdampak langsung terhadap menurunnya jumlah pangan yang dapat diproduksi di suatu wilayah dengan asumsi produktivitas lahan adalah tetap. Tentu saja fenomena ini dapat berpengaruh terhadap pemenuhan kebutuhan pangan masyarakat. Saat kebutuhan pangan masyarakat dapat terpenuhi dengan baik, yaitu pangan tersedia lebih besar sama dengan jumlah kebutuhan pangan, maka masyarakat tersebut 
dapat dikatakan tahan pangan, sebaliknya saat pangan tersedia lebih kecil dari tingkat kebutuhan pangan masyarakat dapat menunjukkan kondisi masyarakat yang tidak tahan pangan. Ketahanan pangan penduduk di Daerah Istimewa Yogyakarta dapat dilihat pada Tabel 8.

Tabel 8

Ketahanan Pangan Penduduk Di Daerah Istimewa Yogyakarta (2006-2015)

\begin{tabular}{lrrrrl}
\hline Tahun & $\begin{array}{r}\text { Ketersediaan } \\
\text { Beras (Ton) }\end{array}$ & $\begin{array}{r}\text { Total } \\
\text { Kebutuhan } \\
\text { Beras (ton) }\end{array}$ & Selisih (ton) & $\begin{array}{r}\text { Persentase } \\
\text { Pemenuhan } \\
\text { Kebutuhan } \\
\text { Beras (\%) }\end{array}$ & \\
\hline 2006 & $401.071,46$ & $260.646,94$ & $140.424,53$ & 153,88 & Surplus \\
2007 & $323.383,45$ & $236.717,18$ & $86.666,28$ & 136,61 & Surplus \\
2008 & $452.082,47$ & $202.827,01$ & $249.255,46$ & 222,89 & Surplus \\
2009 & $372.167,41$ & $197.317,27$ & $174.850,13$ & 188,61 & Surplus \\
2010 & $363.429,14$ & $219.775,77$ & $143.653,37$ & 165,36 & Surplus \\
2011 & $367.147,62$ & $198.731,36$ & $168.416,26$ & 184,75 & Surplus \\
2012 & $414.351,79$ & $232.905,87$ & $181.445,91$ & 177,91 & Surplus \\
2013 & $517.949,01$ & $248.384,66$ & $269.564,35$ & 208,53 & Surplus \\
2014 & $516.684,23$ & $242.197,12$ & $274.487,11$ & 213,33 & Surplus \\
2015 & $531.047,42$ & $225.160,73$ & $305.886,68$ & 235,85 & Surplus \\
\hline Total & $4.259 .314,00$ & $2.264 .663,90$ & $1.994 .650,09$ & 1887,72 & \\
Rata-rata & $425.931,40$ & $226.466,39$ & $199.465,01$ & 188,77 & \\
\hline Sumber & BPS & & & &
\end{tabular}

Sumber: BPS (2016)

Ketahanan pangan penduduk pada dasarnya dapat tercapai saat jumlah pangan yang tersedia di suatu wilayah dapat mencukupi seluruh kebutuhan pangan masyarakatnya. Ketahanan pangan dapat tercermin dari surplus atau defisit pangan yang terjadi di suatu wilayah. Pangan dengan nilai surplus yang semakin besar di suatu wilayah menunjukkan semakin tingginya tingkat ketahanan pangan masyarakat di wilayah tersebut dan sebaliknya, semakin tinggi deficit pangan yang terjadi menyebabkan semakin rendahnya tingkat ketahanan pangan masyarakat.

Berdasarkan Tabel 8 dapat diketahui bahwa pada periode tahun 2006 hingga tahun 2015 mengalami surplus pangan dengan rata-rata nilai surplus pangan sebesar 199.465,01 ton per tahun. Hal ini menunjukkan bahwa walaupun telah terjadi alih fungsi lahan sawah yang cukup besar selama satu dekade terakhir, produksi pangan tetap dapat memenuhi kebutuhan masyarakat dengan baik. Tingkat pemenuhan kebutuhan pangan penduduk juga sangat tinggi, yaitu rata-rata sebesar 188,77\% per tahun yang artinya bahwa terdapat surplus pangan sebesar 88,77\% per tahun dari hasil produksi pangan. Selain itu, berdasarkan data yang tersaji pada Tabel 8 dapat terlihat persentase pemenuhan kebutuhan pangan penduduk yang semakin meningkat, walaupun terjadi alih fungsi lahan sawah yang cukup besar. Fenomena ini dapat terjadi akibat semakin tingginya produktivitas lahan sawah akibat penerapan kebijakan intensifikasi lahan sawah dan semakin menurunnya tingkat konsumsi pangan (beras) penduduk.

Data pada Tabel 8 memberikan gambaran bahwa alih fungsi lahan pertanian belum memberikan dampak terhadap menurunnya tingkat ketahanan pangan 
masyarakat. Tingkat ketahanan pangan masyarakat justru semakin besar dari tahun ke tahun akibat terjadinya penurunan konsumsi beras per kapita dan meningkatnya produktivitas lahan sawah. Akan tetapi, terjadinya alih fungsi lahan pertanian tetap memberikan dampak terhadap kehilangan hasil produksi pangan. Semakin tinggi alih fungsi lahan sawah yang terjadi, maka akan semakin tinggi pula kehilangan hasil produksi pangan yang terjadi di wilayah tersebut. Oleh karena itu, untuk melihat pengaruh alih fungsi lahan sawah yang menyebabkan hilangnya hasil produksi pangan terhadap tingkat ketahanan pangan penduduk, maka dilakukan analisis dengan membuat skenario tingkat ketahanan pangan penduduk saat tidak terjadi alih fungsi lahan sawah. Pada Tabel 9 berikut ini disajikan data skenario yang terjadi terhadap tingkat ketahanan pangan penduduk jika tidak terjadi alih fungsi lahan sawah.

\section{Tabel 9}

Ketahanan Pangan Penduduk Di Daerah Istimewa Yogyakarta Saat Tidak Terjadi Alih Fungsi Lahan Sawah (2006-2015)

\begin{tabular}{rrrrrl}
\hline Tahun & $\begin{array}{c}\text { Ketersediaan } \\
\text { Beras (Ton) }\end{array}$ & $\begin{array}{c}\text { Total } \\
\text { Kebutuhan } \\
\text { Beras (ton) }\end{array}$ & Selisih (ton) & $\begin{array}{c}\text { Persentase } \\
\text { Kebutuhan } \\
\text { Beras (\%) }\end{array}$ & Keterangan \\
\hline 2006 & $401.071,46$ & $260.646,94$ & $140.424,53$ & 153,88 & Surplus \\
2007 & $325.619,44$ & $236.717,18$ & $88.902,26$ & 137,56 & Surplus \\
2008 & $452.753,33$ & $202.827,01$ & $249.926,33$ & 223,22 & Surplus \\
2009 & $372.192,07$ & $197.317,27$ & $174.874,80$ & 188,63 & Surplus \\
2010 & $363.429,14$ & $219.775,77$ & $143.653,37$ & 165,36 & Surplus \\
2011 & $367.936,38$ & $198.731,36$ & $169.205,02$ & 185,14 & Surplus \\
2012 & $415.037,67$ & $232.905,87$ & $182.131,80$ & 178,20 & Surplus \\
2013 & $517.949,01$ & $248.384,66$ & $269.564,35$ & 208,53 & Surplus \\
2014 & $519.672,42$ & $242.197,12$ & $277.475,30$ & 214,57 & Surplus \\
2015 & $533.991,66$ & $225.160,73$ & $308.830,93$ & 237,16 & Surplus \\
\hline Total & $4.269 .652,59$ & $2.264 .663,90$ & $2.004 .988,69$ & 1892,24 & \\
Rata-rata & $426.965,26$ & $226.466,39$ & $200.498,87$ & 189,22 & \\
\hline Sumber: BPS (2016) & & & & & \\
\end{tabular}

Berdasarkan Tabel 9 dapat diketahui bahwa pada saat alih fungsi lahan sawah tidak terjadi dapat memberikan tambahan surplus pangan di wilayah tersebut. Hal ini dapat terlihat pada nilai rata-rata selisih ketersediaan pangan dan kebutuhan pangan penduduk yang surplus sebesar $200.498,87$ ton per tahun dengan persentase pemenuhan kebutuhan pangan penduduk rata-rata sebesar 189,22\% per tahun. Persentase pemenuhan kebutuhan pangan lebih besar dari 100\% menunjukkan terjadinya surplus pangan penduduk rata-rata sebesar $89,22 \%$ per tahun. Tingkat ketahanan pangan penduduk saat tidak terjadi alih fungsi lahan sawah dan saat terjadi alih fungsi lahan sawah selanjutnya dapat dilakukan analisis beda rerata untuk mengetahui ada tidaknya perbedaan tingkat ketahanan pangan penduduk sebelum dan sesudah terjadinya alih fungsi lahan sawah. Hasil analisis uji beda rerata dapat dilihat pada Tabel 10. 
Tabel 10

Uji Beda Rerata Ketahanan Pangan Penduduk Di Daerah Istimewa Yogyakarta Sebelum dan Sesudah Terjadinya Alih Fungsi Lahan Sawah

\begin{tabular}{lrr}
\hline Keterangan & Sesudah Alih Fungsi & Sebelum Alih Fungsi \\
\hline Nilai Rerata & 188,77 & 189,22 \\
Korelasi & 0,99 & \\
t hitung & $-2,75$ & \\
t tabel & 2,26 & \\
Prob t. & 0,02 & \\
\hline
\end{tabular}

Sumber: Analisis Data Sekunder (2016)

Berdasarkan tabel 10. dapat diketahui bahwa nilai probabilitas $\mathrm{t}$ adalah sebesar 0,02. Nilai tersebut lebih kecil jika dibandingkan dengan alpha 5\%, sehingga berarti bahwa terdapat perbedaan rerata nilai ketahanan pangan penduduk antara sebelum dan sesudah terjadinya alih fungsi lahan sawah. Nilai rerata sebelum terjadinya alih fungsi lahan sawah adalah sebesar 189,22 dan saat terjadi alih fungsi lahan sawah nilai rerata menurun menjadi sebesar 188,77. Nilai korelasi juga menunjukkan angka sebesar 0,99 yang artinya bahwa terdapat hubungan yang sangat erat antara ketahanan pangan penduduk sebelum dan sesudah terjadinya alih fungsi lahan sawah. Hasil analisis tersebut memberikan gambaran bahwa alih fungsi lahan sawah dapat berpengaruh signifikan terhadap tingkat ketahanan pangan penduduk.

\section{Implikasi Kebijakan}

Alih fungsi lahan sawah cukup besar per tahunnya. Hal ini tentu saja dapat mengancam ketersedian pangan (beras) penduduk. Berdasarkan hasil analisis menunjukkan bahwa pada satu dekade terakhir telah terjadi kehilangan hasil produksi beras rata-rata sebesar 1.835,93 ton per tahun. Angka tersebut sangat besar mengingat kehilangan hasil tersebut sesungguhnya dapat digunakan untuk kegiatan konsumsi pangan 28.539 jiwa penduduk per tahun. oleh karena itu, lahan sawah perlu diproteksi dengan baik dengan menggunakan peraturan perundang-undangan yang jelas untuk Lahan Pertanian Pangan Berkelanjutan (LP2B) dan dapat memberikan insentif bagi petani untuk mempertahankan lahan pertanian yang dimilikinya. Insentif ini dapat berupa insentif harga, yaitu memberikan kepastian harga kepada petani, maupun insentif dalam hal pemotongan atau pembebasan pajak tanah sawah yang dikelola oleh petani. Kebijakan ini dapat membantu dalam menambah ketersedian beras bagi penduduk. Selain itu, ketahanan pangan juga dapat dicapai dengan mengurangi tingkat konsumsi pangan per kapita penduduk dengan menggiatkan program diversifikasi pangan, sehingga kebutuhan pangan penduduk dapat menurun. Terjadinya peningkatan jumlah ketersediaan pangan dan menurunnya jumlah kebutuhan pangan dapat menunjang terjaganya ketahanan pangan penduduk.

\section{Kesimpulan}

Alih fungsi lahan sawah dapat berdampak negatif terhadap ketersediaan pangan penduduk. Terjadinya alih fungsi lahan menyebabkan timbulnya potensi 
kehilangan hasil produksi padi dan beras yang dapat dicapai. Alih fungsi lahan sawah yang tidak dapat dikendalikan dengan baik dapat mengancam ketahanan pangan penduduk. Ketahanan pangan penduduk dapat tetap terjaga selama ketersedian pangan penduduk dapat terpenuhi dengan baik. Hal ini dapat dicapai dengan cara menambah/mempertahankan luas lahan sawah, meningkatkan produktivitas lahan, dan mengurangi tingkat konsumsi pangan penduduk.

\section{DAFTAR PUSTAKA}

Badan Pusat Statistik (BPS). (2016). Luas Lahan Menurut Penggunaan. Daerah Istimewa Yogyakarta.

BKPP. (2016). Neraca Bahan Makanan (NBM). Badan Ketahanan Pangan dan Penyuluhan. Jakarta.

Darsono. (2012). Faktor Utama Swasembada Pangan Tingkat Rumah Tangga Petani Lahan Kering di Kabupaten Wonogiri Provinsi Jawa Tengah. SEPA, 9(1), 100116.

Daulay, A. R., P, E. I. K., Barus, B., \& Bambang, P. N. (2016). The Acceptable Incentive Value To Succeed Paddy Land Protection Program in Regency of East Tanjung Jabung, Indonesia. ARPN Journal of Agricultural And Biological Science, 11(8), 307-312.

Demmallino, E. B., Ibrahim, T., \& Karim, A. (2018). Petani Di Tengah Tambang: Studi Fenomenologi Efek Implementasi Kebijakan Terhadap Kehidupan Petani di Morowali ( Studi Kasus Pada Kawasan Lingkar Tambang, Kecamatan Bahodopi , Kabupaten Morowali, Provinsi Sulawesi Tengah ). Jurnal Sosial Ekonomi Pertanian, 14(2), 161-170.

Gardi, C., Panagos, P., Van Liedekerke, M., Bosco, C., \& de Brogniez, D. (2015). Land Take and Food Security: Assessment of land take on the agricultural production in Europe. Journal of Environmental Planning and Management, 58(5), 898-912.

Harahap, F., Silveira, S., \& Khatiwada, D. (2017). Land allocation to meet sectoral goals in Indonesia - An analysis of policy coherence. Land Use Policy, 61(2017), 451-465. https://doi.org/10.1016/j.landusepol.2016.11.033

Hidayat, Y., Ismail, A., \& Ekayani, M. (2017). Rumah Tangga Petani Padi ( Studi Kasus Kecamatan Kertajati Kabupaten Majalengka Jawa Barat ). Jurnal Pengkajian Dan Pengembangan Teknologi Pertanian, 20(2), 171-182.

Jiang, L., \& Zhang, Y. (2016). Modeling Urban Expansion and Agricultural Land Conversion in Henan Province, China: An Integration of Land Use and Socioeconomic Data. Sustainability, 8(9), 920. https://doi.org/10.3390/su8090920

Lastinawati, E. (2010). Diversifikasi Pangan dalam Mencapai Ketahanan Pangan. AgronobiS, 2(4), 11-18.

Linda Dwi Rohmadiani. (2011). Dampak Konversi Lahan Pertanian Terhadap Kondisi Sosial Ekonomi Petani (Studi Kasus: Jalur Pantura Kecamatan Pamanukan Kabupaten Subang). Jurnal Teknik WAKTU, 09(02), 71-81. https:/ / doi.org/ISSN : 1412 - 1867

Mahmood, Z., Iftikhar, S., Saboor, A., Khan, A. U., \& Khan, M. (2016). Agriculture land resources and food security nexus in Punjab, Pakistan: an empirical ascertainment. Food and Agricultural Immunology, 27(1), 52-71. 
https:/ / doi.org/10.1080/09540105.2015.1079593

Millar, J., \& Roots, J. (2012). Changes in Australian agriculture and land use: Implications for future food security. International Journal of Agricultural Sustainability, 10(1), 25-39. https:/ / doi.org/10.1080/14735903.2012.646731

Nurpita, A., Wihastuti, L., \& Andjani, I. Y. (2018). Dampak Alih Fungsi Lahan Terhadap Ketahanan Pangan Rumah Tangga Tani Di Kecamatan Temon, Kabupaten Kulon Progo. Jurnal Gama Societa, 1(1), 103-110.

Prihatin, R. B. (2015). Alih Fungsi Lahan di Perkotaan (Studi Kasus di Kota Bandung dan Yogyakarta). Jurnal Aspirasi, Vol. 6(No. 2), 105-118.

Santosa, S. P. (2017). Kajian Ketersediaan Dan Kebutuhan Konsumsi Beras Di Kabupaten Karanganyar, Jawa Tengah. Jurnal Bumi Indonesia, 6(4), 3-11.

Saputra, I. G. S. W., \& Budhi, M. K. S. (2015). Studi Alih Fungsi Lahan Dan Dampaknya Terhadap Sosial Ekonomi Petani Jambu Mete Di Kecamatan Kubu, Kabupaten Karangasem. Jurnal Ekonomi Dan Bisnis, 08(4), 555-570.

Sukesi, K., \& Shinta, A. (2011). Diversifikasi Pangan Sebagai Salah Satu Strategi Peningkatan Gizi Berkualitas Di Kota Probolinggo ( Studi Kasus Di Kecamatan Kanigaran ). SEPA, 7(2), 85-90.

Sunanto, \& Rauf, A. W. (2018). Respon Petani Terhadap Pelaksanaan Displai Padi Gogo VUB Pada Lahan Sub Optimal. Jurnal Sosial Ekonomi Pertanian, 14(2), 143160.

Swaminathan, M. S., \& Bhavani, R. V. (2013). Food production \& availability Essential prerequisites for sustainable food security. Indian Journal of Medical Research, 138(SEP), 383-391.

Wahed, M. (2015). Pengaruh Luas Lahan, Produksi, Ketahanan Pangan dan Harga Gabah Terhadap Kesejahteraan Petani Padi di Kabupaten Pasuruan. Jesp, 7(1), 68-74.

Yasar, M., \& Siwar, C. (2016). Paddy Field Conversion in Malaysia: Issues and Challenges. Rona Teknik Pertanian, 9(2), 168-177. 